\title{
Structure of the parasite infracommunity of Sciades proops from the Japaratuba River Estuary, Sergipe, Brazil
}

\author{
R. P. S. Carvallho ${ }^{a}$, R. M. Takemoto ${ }^{b}$, C. M. Meloc, V. L. S. Jeraldo ${ }^{c}$ and R. R. Madi ${ }^{c *}$
}

aPrograma de Pós-graduação em Saúde e Ambiente, Universidade Tiradentes - UNIT, Av. Murilo Dantas, 300, Farolândia, CEP 49032-490, Aracaju, SE, Brazil
bNúcleo de Pesquisas em Limnologia, Ictiologia e Aquicultura - Nupélia, Laboratório de Ictioparasitologia, Universidade Estadual de Maringá - UEM, Av. Colombo, 5790, Campus Universitário, CEP 87020-900, Maringá, PR, Brazil 'Instituto de Tecnologia e Pesquisa - ITP, Universidade Tiradentes - UNIT, Av. Murilo Dantas, 300, Farolândia, CEP 49032-490, Aracaju, SE, Brazil
*e-mail: rrmadi@gmail.com

Received: February 19, 2014 - Accepted: July 15, 2014 - Distributed: November 30, 2015

(With 2 figures)

\begin{abstract}
The catfish species Sciades proops inhabits muddy estuaries and shallow brackish lagoons, as well as freshwater. For these reasons, it is believed that this species may act as an intermediate, definitive and paratenic host in the life cycle of many parasites. From November 2010 to November 2011 and from August 2012 to July 2013, a total of 126 specimens of Sciades proops from the estuarine region of the Japaratuba River in the state of Sergipe, Brazil, were examined for parasites, of which $84.13 \%$ were infected by at least one species: Ergasilus sp. (Copepoda) (Prevalence $\mathrm{P}=77.78 \%$, Mean of Intensity $\mathrm{MI}=10.08 \pm 15.48$, Mean Abundance MA $=14.27 \pm 7.48$ ) in the gills, Contracaecum sp. $(\mathrm{P}=23.02 \%, \mathrm{MI}=20.59 \pm 80.58, \mathrm{MA}=39.12 \pm 4.47)$ in the general cavity, Procamallanus sp. $(\mathrm{P}=0.79 \%, \mathrm{MI}=1, \mathrm{MA}=0.01 \pm 0.09)$, Raphidascaroides $\mathrm{sp} .(\mathrm{P}=2.31 \%, \mathrm{MI}=1.33 \pm 0.58, \mathrm{MA}=0.33 \pm 0.22)$ and Cuccullanus sp. (Nematoda) $(\mathrm{P}=0.79 \%, \mathrm{MI}=1, \mathrm{MA}=0.01 \pm 0.09)$ in the intestine, Ancyrocephalinae (Monogenea) $(\mathrm{P}=0.79 \%, \mathrm{MI}=1, \mathrm{MA}=0.01 \pm 0.09)$ in the gills, Pseudoacanthostomum panamense $(\mathrm{P}=1.59 \%, \mathrm{MI}=9.00 \pm 8.49$, $\mathrm{MA}=0.14 \pm 1.36)$ in the intestine, Clinostomum sp. $(\mathrm{P}=1.59 \%, \mathrm{MI}=17.50 \pm 23.33, \mathrm{MA}=0.29 \pm 3.03)$ on the body surface and two unidentified metacercariae, referred to as Metacercaria $1(\mathrm{P}=0.79 \% ; \mathrm{IM}=1, \mathrm{MA}=0.01 \pm 0.09)$ and Metacercaria 2 (Digenea) $(\mathrm{P}=0.79 \%, \mathrm{MI}=7, \mathrm{MA}=0.06 \pm 0.62)$ in the swim bladder. Ergasilus sp. was the dominant species and thus classified as core, with Contracaecum sp. as the satellite and other species as secondary species. The spatial distribution of infection with Ergasilus sp. and Contracaecum sp. showed a typical pattern of aggregate distribution. The sex of the host did not influence parasitic infections, but infection with Ergasilus sp. showed a positive and significant correlation with biometric and epidemiologic parameters, whereas infection with Contracaecum sp. was correlated only with prevalence and abundance.
\end{abstract}

Keywords: parasite infracommunity, estuary fish, Sciades proops, Japaratuba River, Brazil.

\section{Estrutura da infracomunidade parasitária de Sciades proops (Valenciennes, 1840) (Siluriformes, Ariidae) do Estuário do Rio Japaratuba, Sergipe, Brasil}

\section{Resumo}

A espécie de bagre Sciades proops habita principalmente estuários de águas rasas enlameada e lagoas salobras, ocorrendo também em águas doces. Por esses motivos acredita-se que essa espécie pode atuar como hospedeiro intermediário, definitivo e paratênico no ciclo de vida de vários parasitas. Entre novembro de 2010 a novembro de 2011 e de agosto de 2012 a julho de 2013, Um total de 126 espécimes de Sciades proops originários da região estuarina do rio Japaratuba, município de Pirambu, SE, foram examinados em busca de parasitas, dos quais $84,13 \%$ estavam parasitados por pelo menos uma espécie de parasita encontrada: Ergasilus sp. (Copepoda) (Prevalência (P)=77,78\%; Intensidade Média (IM) $=10,08 \pm 15,48$, Abund Ância Média $(\mathrm{AM})=7,48 \pm 14,27)$ nas brânquias, Contracaecum $\mathrm{sp} .(\mathrm{P}=23,02 \% ; \mathrm{IM}=20,59 \pm 80,58$, $\mathrm{AM}=4,47 \pm 39,12)$ na cavidade geral, Procamallanus sp. ( $\mathrm{P}=0,79 \% ; \mathrm{IM}=1, \mathrm{AM}=0,01 \pm 0,09)$, Raphidascaroides $\mathrm{sp}$. ( $\mathrm{P}=2,31 \% ; \mathrm{IM}=1,33 \pm 0,58, \mathrm{AM}=0,33 \pm 0,22)$ e Cuccullanus $\mathrm{sp} .(\mathrm{P}=0,79 \% ; \mathrm{IM}=1, \mathrm{AM}=0,01 \pm 0,09)$ (Nematoda) no intestino, Ancyrocephalinae (Monogenea) $(\mathrm{P}=0,79 \%$; $\mathrm{IM}=1, \mathrm{AM}=0,01 \pm 0,09)$ nas brânquias, Pseudoacanthostomum panamense $(\mathrm{P}=1,59 \% ; \mathrm{IM}=9,00 \pm 8,49, \mathrm{AM}=0,14 \pm 1,36)$ no intestino, Clinostomum sp. $(\mathrm{P}=1,59 \% ; \mathrm{IM}=17,50 \pm 23,33$, $\mathrm{AM}=0,29 \pm 3,03)$ na superfície do corpo e duas metacercárias não identificadas, denominadas como Metacercária 1 $(\mathrm{P}=0,79 \% ; \mathrm{IM}=1, \mathrm{AM}=0,01 \pm 0,09)$ e Metacercária $2(\mathrm{P}=0,79 \% ; \mathrm{IM}=7, \mathrm{AM}=0,06 \pm 0,62)$ (Digenea) ambas na bexiga 
natatória. Ergasilus sp. foi a espécie dominante sendo classificada como central, Contracaecum sp. como a satélite e as demais como espécies secundárias. A distribuição espacial da infecção por Ergasilus sp. e Contracaecum sp. apresentaram um padrão típico de distribuição agregada. O sexo dos hospedeiros não influenciou nas infecções parasitárias, porém a infecção por Ergasilus sp. apresentou correlação positiva e significativa entre os parâmetros biométricos e os parâmetros epidemiológicos enquanto que na infecção por Contracaecum sp. a correlação ocorreu apenas com a prevalência e a abundância.

Palavras-chave: infracomunidade parasitária, peixe estuarino, Sciades proops, Rio Japaratuba, Brasil.

\section{Introduction}

The study of the characteristics of parasitic infection in fish, in conjunction with the analysis of the structure of the parasite community and the use of ecological parameters, such as species richness and diversity measures, provide input for future work on the monitoring and evaluation of environmental health in aquatic ecosystems and help to expand the knowledge base on parasite-host relationships (Schmidt et al., 2003a, b; Luque et al., 2004).

The catfish Sciades proops (Valenciennes, 1840), popularly known as "uritinga", are fish of the order Siluriformes, family Ariidae, occurring in tropical and subtropical coastal zones in marine, estuarine and inland waters, and they are generally most abundant in shallow coastal waters with a muddy or sandy bottom (Araújo, 1988; Andreatta et al., 1989). This species is distributed from the Caribbean Sea down the coast to the north coast of Bahia (Froese and Pauly, 2013). Estuarine and coastal areas are considered places of feeding, breeding and shelter for these species and, during the spawning season, many species of marine catfish usually move to estuarine and lagoon areas (Gurgel et al., 2000). By adopting feeding habits based mostly on fish and crustaceans that inhabit estuaries and regions where biodiversity is most abundant, $S$. proops can serve as intermediate, definitive or paratenic hosts of various species of parasites.

This work aims to study the characteristics of parasitic infection and community structure of metazoan parasites present in S. proops catfish collected in the Japaratuba River estuary in the state of Sergipe, Brazil, and examine the relationship between parasitic infection and the biological characteristics of the host.

\section{Material and Methods}

This study was conducted over two periods: November 2010 to November 2011 and August 2012 to July 2013. The $S$. proops specimens were acquired from artisanal fishers in the coastal and estuarine zones of the Japaratuba River, Pirambu County, SE, Brazil. The fish were cooled on ice and transported to the laboratory in a thermal box, weighed, measured and then necropsied. Initially, an external examination of the body surface of the host, including the fins, was conducted to search for ectoparasites. We then proceeded to open the visceral cavity to expose the following organs, which were analyzed to verify the presence of parasites: muscles, general and opercular cavity, intestine, stomach, swim bladder, liver, pancreas, gallbladder, heart and gills (Eiras et al., 2006). For the study of monogeneans and copepods, the gills were isolated whole and placed in water at $56^{\circ} \mathrm{C}$ with vigorous agitation for one minute. Then, the supernatant was placed in a Petri dish and monogeneans were counted and fixed in $5 \%$ formaldehyde and 70\% alcohol. (Kritsky et al., 1995; Eiras et al., 2006; Vianna et al., 2008). The branchial arches were separated in a Petri dish and taken to the stereoscope for analysis; any specimens of copepods that were found were preserved in 70\% alcohol and then clarified in $85 \%$ lactic acid for identification (Tavares and Luque, 2001). The trematodes were compressed between two slides and preserved in formalin-acetic acid, and subsequently stained with acidified carmine (Langeron, 1949). Nematodes were killed in hot $0.15 \mathrm{M}$ saline solution and preserved in $80 \%$ alcohol 10\% glycerin (Eiras et al., 2006). Later, any nematodes collected were clarified in lactophenol (Fagerholm, 1979).

The prevalence $(\mathrm{P})$, mean intensity of infection (MI) and mean abundance (MA) were calculated based on the definitions presented by Bush et al. (1997). Fish were separated into two groups (infected by any parasite species vs. not infected at all), and the intensity of infection was then calculated. Finally, the Condition Factor - Kn (Le Cren, 1951) from each group was computed to analyze the influence of parasitism in fish development. The frequency of dominance, shared dominance and mean relative dominance was calculated according to the procedure described by Rohde et al. (1995) and analyzed as described by Bush and Holmes (1986). The spatial distribution of parasitic infections was checked by calculating the index of aggregation (k) as described by Ludwig and Reynolds (1988). The Simpson diversity index of parasite species analyzed (Ludwig and Reynolds, 1988; Magurran, 2006) and the inter-species association indices of Jaccard, Dice and Ochiai (Janson and Vegelius, 1981; Poulin and Valtonen, 2001) were calculated.

Statistical analyses involving epidemiological indices were performed using only parasite species that showed a prevalence above $10 \%$, except for the analysis of relative condition, in which the overall prevalence of all parasite species was used. Student's t-test was performed to compare the mean Kn of parasitized and non-parasitized groups. To test the influence of sex on the prevalence of parasitism, the chi-square test was performed with a Yates correction and $2 \times 2$ contingency table. We used the nonparametric Mann-Whitney test to assess the influence of sex on infection intensity and mean abundance. We calculated the 
Pearson correlation coefficient to test the influence of weight and total length on the prevalence of parasitism, and the Spearman correlation coefficient to verify the correlation between weight, total length, mean intensity of infection and abundance When necessary, data transformation was applied using $\log (\mathrm{n}+1)$ and statistical analyses were performed using a confidence interval of $95 \%$.

\section{Results}

A total of 126 Sciades proops specimens with mean total length of $27.40 \mathrm{~cm}( \pm 4.98 \mathrm{SD})$ and mean weight of $179.03 \mathrm{~g}( \pm 103.06 \mathrm{SD})$, with 42 females and 84 males, were examined. Overall, $61.11 \%$ were parasitized by one species of metazoa, $19.84 \%$ were parasitized by two species, and $3.17 \%$ harbored three species, for a total prevalence of $84.13 \%$. One thousand six hundred fifty-three parasite specimens (1,013 adults and 640 larvae) belonging to 10 species were collected: Ergasilus sp. (Copepoda), Contracaecum sp., Procamallanus sp., Raphidascaroides sp. and Cuccullanus sp. (Nematoda), Ancyrocephalinae (Monogenea), Pseudoacanthostomum panamense,
Clinostomum sp. and two unidentified metacercariae referred to as Metacercaria 1 and Metacercaria 2 (Digenea). Epidemiological indices and sites of infection are shown in Table 1.

No significant difference was found between the mean $\mathrm{Kn}$ of parasitized $(\mathrm{KnP}=0.94 \pm 0.21)$ and non-parasitized $(\mathrm{KnNP}=1.00 \pm 0.38)(\mathrm{p}=0.32)$ specimens

There was a statistically significant difference in the total prevalence (considering all parasites species) of parasitism between male specimens $(47.62 \%)$ and female specimens (30.15\%) (Table 2).

Weight was positively and significantly correlated with the intensity and the mean abundance of Ergasilus sp. infection and total length was positively and significantly correlated with all epidemiological parameters. With regard to Contracaecum sp. Infection, only the prevalence and mean abundance showed a positive and significant correlation with weight and length (Table 3 ).

The copepod Ergasilus sp. was considered the dominant species, with a higher frequency of cases in which the intensity was greater than that of other species, followed

Table 1. Epidemiological parameters of infection by metazoan parasites of Sciades proops from the Japaratuba River estuary, SE, Brazil.

\begin{tabular}{|c|c|c|c|c|c|}
\hline & $\begin{array}{c}\text { Prevalence } \\
\% \\
\%\end{array}$ & Range & $\begin{array}{c}\text { Mean Intensity } \\
( \pm \text { SD })\end{array}$ & $\begin{array}{c}\text { Mean Abundance } \\
( \pm \text { SD }) \\
\end{array}$ & Site of infection \\
\hline Ergasilus sp. & 77.78 & $1-101$ & $10.08( \pm 15.48)$ & $7.84( \pm 14.27)$ & Gills \\
\hline Contracaecum sp. & 23.02 & $1-437$ & $20.59( \pm 80.58)$ & $4.74( \pm 39.12)$ & General cavity \\
\hline Procamallanus sp. & 0.79 & NA & 1 & $0.01( \pm 0.09)$ & Intestine \\
\hline Raphidascaroides sp. & 2.31 & $1-2$ & $1.33( \pm 0.58)$ & $0.03( \pm 0.22)$ & Intestine \\
\hline Cuccullanus sp. & 0.79 & NA & 1 & $0.01( \pm 0.09)$ & Stomach \\
\hline Ancyrocephalinae & 0.79 & NA & 1 & $0.01( \pm 0.09)$ & Gills \\
\hline $\begin{array}{l}\text { Pseudoacanthostomum } \\
\text { panamense }\end{array}$ & 1.59 & $3-15$ & $9.00( \pm 8.49)$ & $0.14( \pm 1.36)$ & Intestine \\
\hline Clinostomum $\mathrm{sp}$ & 1.59 & $1-34$ & $17.50( \pm 23.33)$ & $0.29( \pm 3.03)$ & Body surface \\
\hline Metacercaria 1 & 0.79 & NA & 1 & $0.01( \pm 0.09)$ & Swim bladder \\
\hline Metacercaria 2 & 0.79 & NA & 7 & $0.06( \pm 0.62)$ & Swim bladder \\
\hline
\end{tabular}

$\mathrm{SD}$ - standard deviation NA - not applicable.

Table 2. Influence of sex on the prevalence, mean intensity and mean abundance of parasitic infection in Sciades proops from the Japaratuba River estuary, SE, Brazil. $\left(\mathrm{X}^{2}\right)$ Chi-square test with Yates correction; (U) Mann-Whitney test.

\begin{tabular}{|c|c|c|c|c|c|c|}
\hline & \multicolumn{2}{|c|}{ Prevalence } & \multicolumn{2}{|c|}{ Mean Intensity } & \multicolumn{2}{|c|}{ Mean Abundance } \\
\hline & $\mathbf{X}^{2}$ & $\mathbf{p}$ & $\mathbf{U}$ & $\mathbf{p}$ & $\mathbf{U}$ & p \\
\hline Ergasilus sp. & 4.83 & 0.03 & 1109.5 & 0.83 & 1458.5 & 0.11 \\
\hline Contracaecum sp. & 0.95 & 0.33 & 68.0 & 0.65 & 1593.0 & 0.38 \\
\hline
\end{tabular}

Table 3. Influence of weight and total length (TL) on the prevalence, mean intensity and mean abundance of infection by Ergasilus sp. and Contracaecum sp. in Sciades proops from the Japaratuba River estuary, SE, Brazil. (r) Pearson correlation coefficient, (rs) Spearman correlation coefficient.

\begin{tabular}{|c|c|c|c|c|c|c|c|}
\hline & \multicolumn{2}{|c|}{ Prevalence } & \multicolumn{2}{|c|}{ Mean Intensity } & \multicolumn{2}{|c|}{ Mean Abundance } \\
\hline & & $\mathbf{r}$ & p & rs & p & rs & p \\
\hline \multirow[t]{2}{*}{ Ergasilus sp. } & Weight & 0.1474 & 0.10 & 0.3590 & $<0.01$ & 0.3216 & $<0.01$ \\
\hline & Total Length & 0.1976 & 0.03 & 0.4005 & $<0.01$ & 0.3674 & $<0.01$ \\
\hline \multirow[t]{2}{*}{ Contracaecum sp. } & Weight & 0.3784 & $<0.01$ & -0.0451 & 0.82 & 0.3575 & $<0.01$ \\
\hline & Total Length & 0.4058 & $<0.01$ & 0.0369 & 0.85 & 0.4041 & $<0.01$ \\
\hline
\end{tabular}


Table 4. Analysis of dominance of metazoan parasites of Sciades proops from the Japaratuba River estuary, SE, Brazil. (SD - standard deviation).

\begin{tabular}{lccc}
\hline & $\begin{array}{c}\text { Frequency of } \\
\text { Dominance }\end{array}$ & Shared Dominance & $\begin{array}{c}\text { Mean relative } \\
\text { dominance } \pm \text { SD }\end{array}$ \\
\hline Ergasilus sp. & 89 & 1 & $7.38 \pm 14.35$ \\
Contracaecum sp. & 11 & 1 & $4.21 \pm 39.13$ \\
Pseudoacanthostomum panamense & 1 & - & $0.11 \pm 1.33$ \\
Clinostomum sp. & 2 & - & $0.27 \pm 3.02$ \\
Metacercaria 1 & 1 & - & $0.05 \pm 0.62$ \\
\hline
\end{tabular}
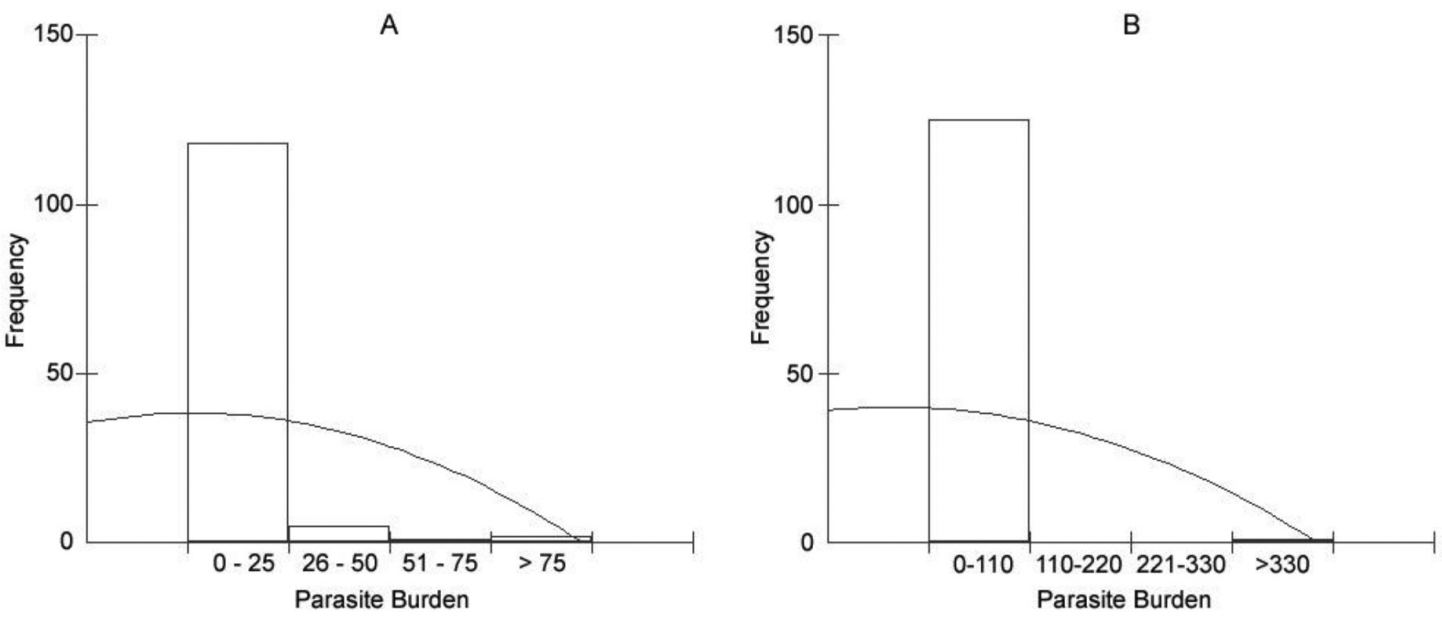

Figure 1. Spatial distribution of infection by Ergasilus sp. (A) and Contracaecum sp. (B) in Sciades proops from the Japaratuba River estuary, SE, Brazil.

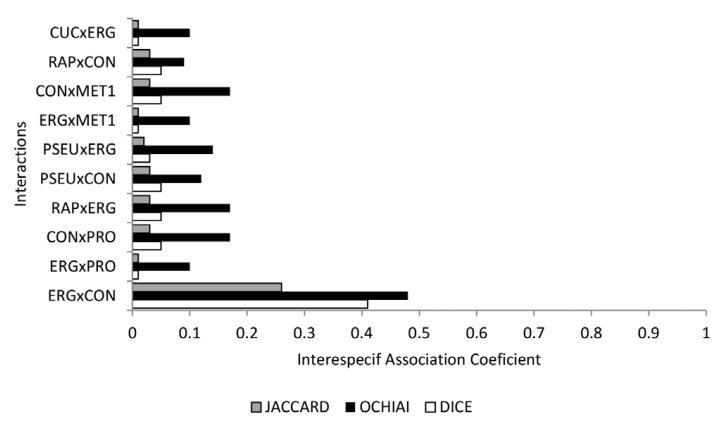

Figure 2. Inter-species associations between pairs of parasite species in Sciades proops from the Japaratuba River estuary, SE, Brazil. (ERG - Ergasilus sp.; CON -. Contracaecum sp.; PRO -. Procamallanus sp.; RAP -. Raphidascaroides sp.; CUC - Cuccullanus sp.; PSEU -. Pseudoacanthostomum panamense; MET1 - Metacercaria 1).

by Contracaecum sp. (Table 4). Both species showed an aggregated distribution pattern, i.e., a high concentration of parasites in a few infected hosts (Ergasilus sp. $\mathrm{k}=0.31$; Contracaecum sp. $\mathrm{k}=0.01$ - Figure 1), as demonstrated by the Simpson diversity index (0.49).

All inter-species association indices showed low interaction between pairs of parasite species, denoting independent relationships between different types of parasitic infection (Figure 2).

\section{Discussion}

Several factors can influence the composition of the parasite fauna of fish, including food, sex of the host, physical and chemical parameters of water, stocking density of fish, etc... (Pavanelli et al., 2002; Madi and Ueta, 2012). The feeding habits of hosts are among the most influential factors in the formation of the parasitic fauna (Bell and Burt, 1991). Piscivorous species tend to harbor more species of parasites because they feed on other already infected fish, and other animals that serve as intermediate hosts of various parasitic groups (Reid, 1983).

In their study of the structure of the parasitic fauna of the white catfish Netuma barba (Ariidae), a demersal fish that occurs in marine and estuarine environments and seeks the mouths of rivers and lagoon areas at spawning time, Tavares and Luque (2004) found that Copepoda was the most abundant taxon, representing $37.5 \%$ of total parasites collected. Similarly, in S. proops, the prevalence of the same taxon was $77.8 \%$. Moreover, six species of copepods were found in N. barba whereas only Ergasilus sp. was found in S. proops. Tavares and Luque (2004) found that copepods are the main components of the parasite community of adult 
N. barba, and suggested that a sample containing only adult individuals can influence the observed abundance and prevalence of these ectoparasites compared to other endoparasites. In the present study, Ergasilus sp. was the species with the highest prevalence in both young and adult Sciades proops specimens. According to Araújo (1988), adult marine catfish feed little during the time of incubation after spawning, for a period that may extend up to three months; during this time, they exhibit lower conditioning factors, which may indicate deficiencies in physiological wellness. This decreased feeding may contribute to reduced exposure of $S$. proops to the probable intermediate hosts of digeneans and nematodes. In contrast, ectoparasites are influenced by the size of the hosts, as well as the degree of specialization of the means of attachment and the availability of infective forms of certain population host groups (Poulin, 2000).

Torres et al. (2000) reported that variations in the infection parameter of anisakids in fish species are related in part to the presence of definitive hosts, environmental factors, such as temperature, that influence the development of the parasite eggs, populations of intermediate or paratenic host crustaceans, as well as the age, size and feeding habits of the fish. Madi and Silva (2005) studied infection by Contracaecum larvae in Rhamdia quelen and found that fish smaller than $20 \mathrm{~cm}$ had no larval parasites whereas larger fish did, a finding that the authors attributed to a difference in diet quality.

The results obtained regarding the relative conditioning factor of $S$. proops suggest that parasitic infections do not influence the general health of the fish.

According to Esch et al. (1988), the sex of the host could be a decisive and influential factor and Fernandez (1985) explains that this could be due to differences in diet composition between males and females, as well as differences in behavior and physiological resistance. However, Dias et al. (2004) and Ferreira (2008) found that males and females showed no significant differences with respect to the intensities and frequencies of parasitism, in disagreement with the results obtained in the present study. Ferreira (2008) believes that males and females have the same behavior in relation to food habits and habitat and thus have the same chances of infection. However, in a study of the ecological aspects and the biodiversity of parasites in the catfish $S$. proops, it was noted that the males of this species are involved in parental care, carrying juvenile offspring in the mouth and spending more time in the estuary, the place where the sampling occurred, whereas females return to the marine region after fertilization.

In the work of Tavares and Luque (2004), none of the species of parasites found in $N$. barba demonstrated an effect of host sex on abundance and prevalence. The observed abundance was similar to the present study, but the total prevalence (considering all species of parasites) differed: in this study we found a significant difference between males $(47.62 \%)$ and females $(30.15 \%)$.

Weight and total length influenced the prevalence, mean intensity and mean abundance of Ergasilus sp. in $S$. proops. Dias et al. (2004) suggest that the highest intensity of parasitism in larger specimens is explained by the progressive accumulation of parasites over time. For ectoparasites, the observed correlation between morphometric and ecological parameters may be related to environmental factors such as quantity of organic material present in water or solid materials in suspension (Madi and Ueta, 2009). However, for Contracaecum sp. weight and length influenced only the prevalence and mean abundance. Tavares and Luque (2004) did not observe a correlation between the total length of the host and frequency of nematode parasites, in contrast with the results of the present study. Koya and Mohandas (1982) observed that, in general, the frequency of nematodes is higher among juveniles, although intensity is higher among older fish; this finding also differs from the results of this study, in which larger size was negatively correlated with the intensity of infection. According to Cordeiro and Luque (2005), few helminth species are influenced by host length, which has almost no influence on the parasite load. According Polyanski (1961), negative correlations can be caused by temporal segregation of a particular food item.

Sasal et al. (1999) noted that large fish may feed more and thus have greater likelihood of ingesting intermediate hosts. Host length is indicative of the expected parasite burden and Dogiel (1964) notes that a variety of factors can determine or influence the parasitic fauna of many species or groups of hosts: age, sex, size, type of food, lifestyle. In addition to biological factors, the geographical and seasonal distribution of the host population over time and space can influence the intensity of infection (Timi and Poulin, 2003; Vidal-Martinez and Poulin, 2003). Freeman (1964) found that, in general, younger fish were more infected than older fish, consistent with the findings regarding infection by Contracaecum larvae in this work. The length of the fish can be considered a reflection of age, which is one of the most influential factors in the variation of parasitic infrapopulations and accumulation of parasites throughout the lifespan (Alves and Luque, 2001).

In a study of the structure of the parasite community of Pseudoplatystoma. tigrinum Lopes (2006) found a dominance relationship between host fish and nematode larvae, and explained this result by the fact that a single host showed a high intensity of larvae in the mesentery. In $S$. proops, a large quantity of Contracaecum was also found in the mesentery (497) in a single specimen, but there was no dominance relationship between this parasite and others. This finding supports the hypothesis that many hosts harbor few parasites and few hosts harbor many parasites (Anderson and Gordon, 1982). All the N. barba parasites found by Tavares and Luque (2004) showed the typical pattern of aggregate distribution similar to $S$. proops. The spatial distribution of Ergasilus sp. and Contracaecum sp. parasites also presented an aggregate pattern.

One of the most common features in parasitic infections in vertebrate hosts is the tendency of parasites to present an aggregate distribution in their hosts (Von Zuben, 1997). Most hosts tend to harbor few parasites, whereas few hosts 
contain most of the parasite population (Poulin, 1993). This suggests that density-dependent processes, such as the suppression of fertility or survival of the parasite, may have an effect (Anderson and Gordon 1982). The Ergasilus sp. and Contracaecum sp. parasites found in the hosts in this study followed the pattern of aggregate distribution $(\mathrm{k}=0.31$ and $\mathrm{k}=0.01$, respectively). The model of aggregate dispersion can be due to (1) the heterogeneity of host behavior, (2) models of spatial aggregation in the distribution of infective stages, and (3) differences in host susceptibility and immune response (Anderson and Gordon, 1982; Von Zuben, 1997).

The most prevalent species occupy core and satellite positions within the community and are therefore more widely distributed, with a high dispersion power (Kennedy, 2001). The Ergasilus copepods occupied a central position within the $S$. proops parasite infracommunity, whereas Contracaecum sp. larvae acted as satellite species and other parasitic species as secondary. Generally, ectoparasite species occupy the position of satellites in the host species because they live on the outer surface of the body and may be lost during handling and transportation of the fish.

It is believed that satellite species have a low transmission rate and have less potential to colonize their hosts, which may be related to a lower availability of intermediate hosts and infective forms (Sousa, 1994).

Rohde et al. (1995) designated unsaturated communities as those in which abundance, prevalence and species richness can vary widely, with common vacant niches and some parasites forming disordered clusters defined by varying degrees of exposure to infection. This characteristic pattern of major parasites of Sciades proops was observed in this work.

\section{Acknowledgements}

The authors thank CAPES - PROCAD NF 2009 by financial support, the Tiradentes University for the scholarship PROCAPS Type II for Renata P. S. Carvalho. Lumara S. A. Bonfim and Carolina Roza for technical support.

\section{References}

ALVES, R.A. and LUQUE, J.L., 2001. Aspectos quantitativos das infrapopulações de metazoários parasitos de Micropogonias furnieri (Osteichthyes: Scianidae) do litoral do estado do Rio de Janeiro, Brasil. Parasitologia al día, vol. 25, no. 1-2, pp. 30-35. http://dx.doi.org/10.4067/S0716-07202001000100006.

ANDERSON, R.M. and GORDON, D.M., 1982. Processes influencing the distribution of parasite numbers within host populations with special emphasis on parasite-induced host mortalities. Parasitology, vol. 85, no.2, pp. 373-398. http://dx.doi. org/10.1017/S0031182000055347. PMid:7145478.

ARAÚJO, F.G., 1988. Distribuição, abundância relativa e movimentos sazonais de bagres marinhos (Siluriformes, Ariidae) no estuário da lagoa dos Patos (RS), Brasil. Revista Brasileira de Zoologia, vol. 5, no. 4, pp. 509-543. http://dx.doi.org/10.1590/ S0101-81751988000400002.
BELL, G. and BURT, A., 1991. The comparative biology of parasite species diversity: internal helminths of freshwater fish. Journal of Animal Ecology, vol. 60, no. 3, pp. 1047-1064. http:// dx.doi.org/10.2307/5430.

BUSH, A.O. and HOLMES, J.C., 1986. Intestinal helminths of lesser scaup ducks: an interactive community. Canadian Journal of Zoology, vol. 64, no. 1, pp. 142-152. http://dx.doi. org/10.1139/z86-023.

BUSH, A.O., LAFFERTY, D.K., LOTZ, J.M. and SHOSTAK, A.W., 1997. Parasitology meets ecology on its own terms: Margolis et al. revisited. The Journal of Parasitology, vol. 83, no. 4, pp. 575-583. http://dx.doi.org/10.2307/3284227. PMid:9267395.

CORDEIRO, A.S. and LUQUE, J.L., 2005. Metazoários parasitos do coió Dactylopterus volitans (Linnaeus, 1758) (Osteichthyes: Dactylopteridae) do litoral do Estado do Rio de Janeiro, Brasil. Acta Scientiarum: Biological Sciences, vol. 27, no. 2, pp. 119-123.

DIAS, P.G., FURUYA, W.M., PAVANELLI, G.C., MACHADO, M.H. and TAKEMOTO, R.M., 2004. Carga parasitária de Rondonia rondoni Travassos, 1920 (Nematoda, Atractidae) e fator de condição do armado, Pterodoras granulosos Valenciennes, 1883 (Pisces, Doradidae). Acta Scientiarum: Biological Sciences, vol. 26, no. 2, pp. 151-156.

DOGIEL, V.A., 1964. General parasitology. London: Edinburgh. $516 \mathrm{pp}$.

EIRAS, J.C., TAKEMOTO, R.M. and PAVANELLI, G.C., 2006. Métodos de estudo e técnicas laboratoriais em parasitologia de peixes. 2nd ed. Maringá: Editora UEM. 170 pp.

ESCH, G.W., KENNEDY, C.R., BUSH, A.O. and AHO, J.M., 1988. Patterns in helminth communities in freshwater fish in Great Britain alternative strategies for colonization. Parasitology, vol. 96, no. 3, pp. 519-532. http://dx.doi.org/10.1017/S003118200008015X. PMid:3405638.

FAGERHOLM, H.P., 1979. Nematode length and preservatives, with a method for determining the length of live specimens. The Journal of Parasitology, vol. 65, no. 2, pp. 334-335. http://dx.doi. org/10.2307/3280182. PMid:571912.

FERNANDEZ, B.J., 1985. Estudio parasitológico de Merluccius australis (Hutton, 1982) (Pisces: Merluccidae): Aspectos sistemáticos, estatísticos y zoogeográficos. Boletín de la Sociedad de Biología de Concepción, vol. 56, pp. 31-41.

FERREIRA, M.F., 2008. Frequência de cestóides e nematóides em cinco espécies de peixes teleósteos e sua importância higiênicosanitário. Niterói: Universidade Federal Fluminense. 78 pp. Doctoral Thesis in Veterinary Medicine.

FREEMAN, R.S., 1964. Flatworm problems in fish. Canadian Fish Culturist, vol. 32, pp. 11-18.

FROESE, R. and PAULY, D., 2013 [viewed 3 June 2013]. FishBase [online]. Stockholm, Sweden. Available from: http:// www.fishbase.org/

GURGEL, H.C.B., ALBURQUEQUE, C.Q., SOUZA, D.S.L. and BARBIERI, G., 2000. Aspectos da biologia pesqueira em fêmeas de Cathorops spixii do estuário do rio Potengi, Natal/RN, com ênfase nos índices biométricos. Acta Scientiarum. Biological Sciences, vol. 22, pp. 503-505. 
JANSON, S. and VEGELIUS, J., 1981. Measures of ecological association. Oecologia, vol. 49, no. 3, pp. 371-376. http://dx.doi. org/10.1007/BF00347601.

KENNEDY, C.R., 2001. Metapopulation and community dynamics of helminth parasites of eels Anguilla anguilla in the River Exe system. Parasitology, vol. 122, no. Pt 6, pp. 689-698. http://dx.doi. org/10.1017/S0031182001007879. PMid:11444622.

KOYA, M.S. and MOHANDAS, A., 1982. Helminth parasites of marine fishes of Cochin. Indian Journal of Parasitology, vol. 6, no. 1, pp. 103-105.

KRITSKY, D.C., BOERGER, W.A. and POPAZOGLO, F., 1995. Neotropical Monogenoidea. 22. Variation in Scleroductus species (Gyrodactylidea, Gyrodactylidae) from Siluriform fishes of southeastern Brazil. Journal of the Helminthological Society of Washington, vol. 62, pp. 53-56.

LANGERON, M., 1949. Précis de microscopie. Paris: Brodard \& Taupin. 1430 pp.

LE CREN, E.D., 1951. The length-weight relationship and seasonal cycle in gonadal weight and condition in the perch (Perca fluviatilis). Journal of Animal Ecology, vol. 20, no. 2, pp. 201-219. http://dx.doi.org/10.2307/1540.

LOPES, L.P.C., 2006. Composição e estrutura da comunidade parasitária associada às espécies do gênero Pseudoplatystoma (Bleeker, 1862) (Siluriformes: Pimelodidae) da Amazônia Central, Brasil. Manaus: INPA/Universidade Federal do Amazonas. 34 pp. Master Thesis in Tropical Biology and Natural Resources.

LUDWIG, J.A. and REYNOLDS, J.F., 1988. Statistical ecology: a primer on methods and computing. New York: John Wiley \& Sons. $316 \mathrm{pp}$.

LUQUE, J.L., MOUILLOT, D. and POULIN, R., 2004. Parasite biodiversity and its determinants in coastal marine teleost fishes of Brazil. Parasitology, vol. 128, no. 6, pp. 671-682. http://dx.doi. org/10.1017/S0031182004005050. PMid:15206470.

MADI, R.R. and SILVA, M.S.R., 2005. Contracaecum Railliet \& Henry, 1912 (Nematoda, Anisakidae): o parasitismo relacionado à biologia de três espécies de peixes piscívoros no reservatório do Jaguari, SP. Revista Brasileira de Zoociências, vol. 7, no. 1, pp. 15-24.

MADI, R.R. and UETA, M.T., 2009. O papel de Ancyrocephalinae (Monogenea; Dactylogyridae), parasito de Geophagus brasiliensis (Pisces; Cichlidae), como indicador ambiental. Revista Brasileira de Parasitologia Veterinária, vol. 18, no. 2, pp. 38-41. http:// dx.doi.org/10.4322/rbpv.01802008. PMid:19602315.

MADI, R.R. and UETA, M.T., 2012. Parasitas de peixes como indicadores ambientais. In: A.T. SILVA-SOUZA, MA.P. LIZAMA and R.M. TAKEMOTO, eds. Patologia e sanidade de organismos aquáticos. Maringá: Ed. Massoni, pp. 33-58.

MAGURRAN, A.E., 2006. Ecological diversity and its measurement. Princeton: Princenton Univ. Press. 179 pp.

PAVANELLI, G.C., EIRAS, J.C. and TAKEMOTO, R.M., 2002. Doenças de peixes, diagnóstico, profilaxia e tratamento. Maringá: Editora UEM. 305 pp.

POLYANSKI, Y.I., 1961. Ecology of parasites of marine fishes. In: V.A. Dogiel, G.K. Petrushevski and Y.I. Polyanski, eds. Parasitology of fishes. London: Oliver and Boyd, pp. 48-83.
POULIN, R. and VALTONEN, E.T., 2001. Interespecific association among larval helmints in fish. International Journal for Parasitology, vol. 31, no. 14, pp. 1589-1596. http://dx.doi. org/10.1016/S0020-7519(01)00276-4. PMid:11730785.

POULIN, R., 1993. The disparity between observed and uniform distribuitions: a new look at parasite aggregation. International Journal for Parasitology, vol. 23, no. 7, pp. 937-944. http://dx.doi. org/10.1016/0020-7519(93)90060-C. PMid:8106186.

POULIN, R., 2000. Variation in the intraspecific relationship between fish length and intensity of parasitic infection: biological and statistical causes. Journal of Fish Biology, vol. 56, no. 1, pp. 123-137. http://dx.doi.org/10.1111/j.1095-8649.2000.tb02090.x.

REID, S., 1983. La biologia de los bagres rayados Pseudoplatystoma fasciatum y P. tigrinum em la cuenca del rio Apure, Venezuela. Revista Unellez de Ciência y Tecnologia, vol. 1, pp. 13-41.

ROHDE, K., HAYWARD, C. and HEAP, M., 1995. Aspects of the ecology of metazoan ectoparasites of marine fishes. International Journal for Parasitology, vol. 25, no. 8, pp. 945-970. http://dx.doi. org/10.1016/0020-7519(95)00015-T. PMid:8550295.

SASAL, P., NIQUIL, N. and BARTOLI, pp., 1999. Community structure of digenean parasites of sparid and labrid fishes of the Mediterranean Sea: a new approach. Parasitology, vol. 119, no. 6, pp. 635-648. http://dx.doi.org/10.1017/S0031182099005077. PMid:10633926.

SCHMIDT, V., ZANDER, S., KÖRTING, W. and STEINHAGEN, D., 2003a. Parasites of the flounder Platichthys flesus (L.) from the German Bight, North Sea, and their potential use in ecosystem monitoring. A. Infection characteristics of potential indicator species. Helgoland Marine Research, vol. 57, no. 3, pp. 236-251. http://dx.doi.org/10.1007/s10152-003-0147-1

SCHMIDT, V., ZANDER, S., KÖRTING, W. and STEINHAGEN, D., 2003b. Parasites of the flounder Platichthys flesus (L.) from the German Bight, North Sea, and their potential use in ecosystem monitoring. B. Community structure and fish parasite biodiversity. Helgoland Marine Research, vol. 57, no. 3, pp. 252-261. http:// dx.doi.org/10.1007/s10152-003-0148-0.

SOUSA, W.P., 1994. Patterns and processes in communities of helminth parasites. Trends in Ecology \& Evolution, vol. 9, no. 2, pp. 52-57. http://dx.doi.org/10.1016/0169-5347(94)90268-2. PMid:21236766.

TAVARES, L E.R. and LUQUE, J.L., 2001. Aspectos quantitativos das infrapopulações de Caligus praetextus Bere, 1936 (Copepoda, Caligidae) parasitos do robalo Centropomus undecimalis (Bloch, 1792) (Osteichthyes, Centropomidae) no litoral do estado do Rio de Janeiro, Brasil. Revista Brasileira de Zoociencias, vol. 3, pp. 253-258.

TAVARES, L.E. and LUQUE, J.L., 2004. Community ecology of the metazoan parasites of white sea catfish, Netuma barba (Osteichthyes: Ariidae), from the coastal zone of the State of Rio de Janeiro, Brazil. Brazilian Journal of Biology $=$ Revista Brasileira de Biologia, vol. 64, no. 1, pp. 169-176. http://dx.doi. org/10.1590/S1519-69842004000100019. PMid:15195376.

TIMI, J.T. and POULIN, R., 2003. Parasite community structure within and across host populations of a marine pelagic fish: how repeatable is it? International Journal for Parasitology, vol. 33 , no. 12 , pp. 1353-1362. http://dx.doi.org/10.1016/S00207519(03)00203-0. PMid:14527518. 
TORRES, pp., MOYA, R. and LAMILLA, J., 2000. Nematodos anisakidos de interés en salud pública en peces comercializados en Valvidia, Chile. Archivos de Medicina Veterinaria, vol. 32, no. 1, pp. 107-111. http://dx.doi.org/10.4067/S0301-732X2000000100014.

VIANNA, R.T., BOEGER, W.A. and SILVA-SOUZA, A.T., 2008. Neotropical Monogenoidea. 52. Diechodactylus joaberi n. g., n. sp. from the banded knifefish Gymnotus carapo (Gymnotiformes: Gymnotidae) in southeastern Brazil. Systematic Parasitology, vol. 69, no. 1, pp. 45-50. http://dx.doi.org/10.1007/s11230-0079107-5. PMid:18030601.
VIDAL-MARTINEZ, V.M. and POULIN, R., 2003. Spatial and temporal repeatability in parasite community structure of tropical fish hosts. Parasitology, vol. 127, no. 4, pp. 387-398. http://dx.doi. org/10.1017/S0031182003003792. PMid:14636025.

VON ZUBEN, C.J., 1997. Implicações da agregação espacial de parasitas para a dinâmica populacional na interação hospedeiroparasita. Revista de Saúde Pública, vol. 31, no. 5, pp. 523-530. http:// dx.doi.org/10.1590/S0034-89101997000600014. PMid:9629733. 